Historic, Archive Document

Do not assume content reflects current scientific knowledge, policies, or practices. 


\section{Peonies Only}

\section{A SPECIAL OFFERING OF STANDARD VARIETIES AT ATTRACTIVE PRICES}

This season, our offering will appeal particularly to the nurserymen, florists and seed houses who need the reliable standard kinds for their trade. Also, these varieties will fully satisfy the grower of commercial cut-flowers who demands the best for his particular purpose.

Practically all of the varieties offered in this list are especially adapted to producing profitable crops of commercial cut-flowers.

A variety to be a success as a commercial cut-flower variety, must be a reliable, every year bloomer and reasonably attractive in bud as well as flower. It must have, at least a fair color, and be an easy and perfect opener. Stems must be reasonably long, and it is desirable that the variety be a good shipper and hold well in storage.

Those varieties "underscored" as FESTIVA MAXIMA, we grow in quantity in order to fill the larger orders of $1,000,5,000$ and 10,000 or more. They are popular and profitable cut-flower market varieties which have withstood the acid test of commercial growing, where none but the most reliable and prolific bloomers are tolerated. WE SELL LARGE ORDERS EACH YEAR TO SOME OF THE HEAVIEST BUYERS OF PEONIES AND WE FEEL THAT OUR PEONIES WILL PLEASE YOU.

There is a tremenduous interest in Peonies throughout the country. We advise that you get ready for the heavy demand this fall by placing your order now for Peonies.

\section{General List}

All priced to interest the large buyer.

* EARLY: Usually in bloom in time for Decoration Day.

NOTE: In this list, we have shown "Number of Divisions offered" of such varieties as we have only a small number. Other varieties we can furnish in quantity.

Wholesale Prices Price each in quantities of

$$
\begin{array}{lcc}
\text { Strong } 3 \text { to } 5 \text { eye divisions } & \text { to } & \text { to } \\
& 25 & 100 \\
\text { RE (Dessert 1904) } & & \$ .25
\end{array}
$$

AURORE (Dessert 1904)

Late Semi-rose Type Lilac White

AVIATEUR REYMOND (Dessert 1915) $\$ 1.00$

Midseason Semi-double Type Cherry Red

(Number of Divisions offered 7)

BARONESS SCHROEDER (Kelway 1889)

Late Midseason Rose Type Flesh White One of the outstanding "World's Best Varieties" which we can highly recommend both for commercial cut-1lowers and general planting. Very reliable.

BAYADERE (Lemoine 1910)

Midseason Rose Type Cream White (Number of Divisions offered 15)

LARGE ORDERS: Please submit your "want list." On certain items, in quantity, it is often possible for us to quote lower than printed prices. 
Wholesale Prices Price each in quantities of

Strong 3 to 5 eye divisions

$\begin{array}{cc}5 & 25 \\ \text { to } & \text { to } \\ 25 & 100\end{array}$

CARNEA ELEGANS (Calot 1860)

$$
\text { Midseason Crown Type Flesh Pink }
$$

(Number of Divisions offered 30 )

COURONNE D' OR (Calot 1873)

Late Midseason Semi-rose Type Snow White A variety with fine habits and always dependable. Largely planted for cut flowers.

DELACHEI (Delache 1856)

Late Midseason Rose Type Violet Crimson *DUCHESSE DE NEMOURS (Calot 1856)

Early Midseason

White, Sulphur Center

Crown Type

Vigorous, upright grower and one of the very best bloomers. Blooming as it does, about two days later than Festiva Maxima makes it a valuable kind to use in combination with Festiva Maxima. This is one of the very best commercial cut-flower Peonies and no grower can afford to leave it out of his planting. Good shipper and keeps well in storage.

*EDULIS SUPERBA (Lemon 1824)

Very Early Crown Type Deep Rose Pink ELIZABETH BARRETT BROWNING

(Brand 1907)

Very Late Rose Type

White (Number of Divisions offered 3)

*EUGENIE VERDIER (Calot 1864)

Early Semi-rose Type Shell Pink

EXQUISITE (Kelway 1912)

Midseason Semi-double Type Cherry Rose (Number of Divisions offered 7)

FELIX CROUSSE (Crousse 1881)

Midseason Rose Type Ruby Red Most popular of all red Peonies for Cutflower purposes. In many localities south of the Mason and Dixon line, it is several days earlier and opens much better than the newer variety, Karl Rosefield. Very profuse and reliable bloomer. We can recommend Felix Crousse without reservation.

*FESTIVA MAXIMA (Miellez 1851)

Early Rose Type

White

FLORAL TREASURE (Rosefield 1900)

Midseason Rose Type - Salmon Pink Much used for commercial cut-flowers. A profuse and reliable every year bloomer and is very highly thought of because it is one of the best shippers and keeps a long time in cold storage.

${ }^{*}$ GLOIRE DE CHARLES GOMBAULT (Gom.-Des.)

Early Midseason Crown Type Rose \& Cream

PLACE ORDERS EARLY: We do not substitute unless instructed by customer to do so. Money promptly returned for any varieties we are sold out of. 
Wholesale Prices

Price each in quantities of

Strong 3 to 5 eye divisions

$\begin{array}{cc}5 & 25 \\ \text { to } & \text { to } \\ 25 & 100\end{array}$

*GOLDEN HARVEST (Rosefield 1900)

Early Midseason Bomb Type Pink and Cream

*JEANNE D'ARC (Calot 1858)

Early Midseason Crown Type Pink \& Cream This is one of the Peonies which shows the golden yellow, a color so much desired and admired in Peonies. Strong grower and profuse bloomer and we like it for cut flowers.

L'ECLATANTE (Calot 1860)

Midseason Bomb Type Velvety Crimson

LA FAYETTE (Dessert 1904)

Midseason Rose Type Salmon Pink (Number of Divisions offered 6)

LA FIANCEE (Dessert 1902) (Single)

Very early (Number of Divisions offered 1)

LA FONTAINE (Lemoine 1904)

Late Midseason Bomb Type Violet Rose (Number of Divisions offered 3 )

LA TULIPE (Calot 1872)

Late Midseason. Semi-rose type Delicate Pink

*MADAME AUGUSTE DESSERT(Des. 1899)

Early Midseason Semi-rose Type Flesh Pink

MADAME BUCQUET (Dessert 1888)

Midseason Semi-rose Type Dark Crimson (Number of Divisions offered 25)

MADAME CROUSSE (Calot 1866)

Midseason Crown Type Pure White (Number of Divisions offered 20)

MADAME FOREL (Crousse 1881)

Late Midseason Rose Type Glossy Pink (Number of Divisions offered 30 )

MADAME GAUDICHAU (Millet 1902)

Midseason Semi-double Type Dark Garnet (Number of Divisions offered 2)

MADAME GEISSLER (Crousse 1880)

Midseason Rose Type Rose Pink

MADAME LEMOINIER (Calot 1865)

Midseason Rose Type Lilac Rose

MADEMOISELLE LEONIE CALOT (Calot 1861)

Late Midseason Rose Type Delicate Pink (Number of Divisions offered 50)

MADEMOISELLE ROSSEAU (Calot 1886)

Midseason Semi-rose Type Milk White (Number of Divisions offered 20)

MARCELLE DESSERT (Dessert 1899)

Midseason Crown Type Milk White (Number of Divisions offered 8)

MARECHAL VAILLANT (Calot 1867)

Late Rose Type Light Red

MARQUIS C. LAGERGREN (Dessert 1911)

Midseason Semi-rose Type Bright Crimson. (Number of Divisions offered 6)

LARGE ORDERS: Please submit your "want list." On certain items, in quantity, it is often possible for us to quote lower than printed prices. 
Wholessle Prices

Price each in quantities of

$\begin{array}{cc}5 & 25 \\ \text { to } & \text { to } \\ 25 & 100\end{array}$

Strong 3 to 5 eye divisions

- MADAME DE VERNEVILLE

Early Bomb Type Milk White

is one of the most charming of all varieties. This is an old established and fully tested Peony and for dependability for cut-flowers and general planting is unusually valuable. Early as Festiva Maxima.

MARIE LEMOINE (Calot 1869)

Tery Late Rose Type Ivory White

"Very highly regarded as one of the handsomest Peonies." Desirable in many localities for commercial cut-flowers. One of the best.

MODELE DE PERFECTION (Crousse 1875)

Late Rose Type Violet Rose

(Number of Divisions offered 25)

PRESIDENT ROOSEVELT (Warmaar 1905)

Midseason Semi-rose Type Deep Red

SUZANNE DESSERT (Des. \& Mech. 1890)

Midseason Semi-rose Type China Pink (Number of Divisions offered 18)

TRIOMPHE DE L'EXPO. DE LILLE

$\frac{\text { Midseason (Calot 1865) }}{\text { Rose Type Pale Pink }}$

- UMBELLATA ROSEA (Dessert 1895)

Very Early Rose Type Pink and Cream Strong, upright grower and profuse bloomer. Comes in bloom earlier than any other Peony of the "so called" Chinensis class, which makes it extremely valuable for cutting for the Decoration Day market. A profitable variety.

WELCOME GUEST (Hollis 1904)

Midseason Semi-double Type Bright Rose (Number of Divisions offerd 25)

\section{PEONIES TO COLOR}

These are all good strong growing, prolific blooming Peonies that will be sure to please.

PINK

RED

WHITE AND FLESH SHADES

\section{AN IMPORTANT ANNOUNCEMENT}

In fall of 1930 , we will again offer a wonderful list of the new and scarce varieties, in addition to the standard commercial kinds.

Moving our stock of Peonies to our new eighty acre farm has disturbed our 1929 digging schedule so far as the new and scarce varieties are concerned.

PLACE ORDERS EARLY: We do not substitute unless instructed by customer to do so. Money promptly returned for any varieties we are sold out of. 


\section{Our Peonies Please}

"Yours of the 19th received. Very glad to do business with you Mr. Hardesty. The writer was pleased with your place down there, it looks right and Peonies we received from you last fall were right and that's why we are giving you this order."

Manchester, Conn. (1928)

"The Peonies from you that we planted last season have been doing nicely and almost all of the 5500 ordered for cut-flower trade bloomed." Waynesboro, $\mathrm{Pa}$. (1928)

"The Peonies shipped me on October second were duly received in good condition and wish to thank you for the fine roots sent." Columbus, Ohio. (1928)

"We certainly want to thank you for the prompt service that you have given the telegraph order that we sent to you yesterday. We greatly appreciate your kindness in giving this order special attention. As you know we favor you on all of our orders for Peonies whenever your prices are in line or nearly in line." Philadelphia, Pa. (1928)

"Your shipment of Loveliness came last week and the roots were better than expected, therefore this order."

Lexington, Ky. (1928)

"The Peonies have been received and are very nice."

Bristol, Va. (1928)

"I herewith advise you that when I got home last Saturday afternoon, I found the shipment of plants had already arrived, and found everything in fine shape, and am well pleased with the plants you sent me. As soon as I get everything lined up for next year, I will order a great deal more plants."

Chicago, Ill. (1928)

"The 150 divisions that I purchased from you last year are doing fine."

New Castle, Ind. (1928)

"I was very much pleased with the roots sent me a few weeks ago. They were certainly fine, strong divisions."

Chicago, Ill. (1928)

"Order of October second received in good condition and very nice rocts. Can you send me the following kinds?"

South Euclid, Ohio. (1928)

"Thanks for the good plants."

Liberty, Indiana. (1928)

"We were well pleased with the roots received from you last fall."

New Milford, Conn. (1928)

"Last year's stock you shipped was very satisfactory." Great Barrington, Mass. (1928)

"I am sending you this early order, hoping to get an early shipment. The larger shipment received last year was very satisfactory and I appreciate it."

Ann Arbor, Michigan. (1928)

LARGE ORDERS: Please submit your "want list." On certain items, in quantity, it is often possible for us to quote lower than printed prices. 


\section{Please Read Before Ordering}

SMALL ORDERS: Our prices are very low and at such prices, we cannot fill orders for less than twenty-five of one variety of the lower priced sorts, or five of one variety of the higher priced sorts, except as otherwise quoted.

SIZE OF ROOTS: Our prices are based on liberal, well balanced three to five eye divisions, cut from two and three year roots and which should not be confused with divisions cut from old commercial cut-flower clumps that may have lost much of their vitality. The three to five eye divisions, through years of thorough testing, have proven to be the most satisfactory and economical size to buy and we reccommend them to our customers.

GIVE US SHIPPING INSTRUCTIONS: When ordering please give full shipping address when different from postoffice, and state whether you desire shipment via express or freight.

WHEN WE SHIP: We begin shipping as soon after September first as conditions will permit, and we continue shipping throughout the months of September, October and November, all of which months are equally suitable for successful planting of Peonies. Our Peonies are packed in tight, paper-lined boxes with old, damp sawdust and will carry to destination and keep in good condition for an indefinite period when stored in a cold, dry place

TEPMS: Cash with order, less three per cent from individuals or companies not satisfactorily rated. Otherwise two per cent ten days, net thirty days. Special terms by agreement. All quotations subject to stock being unsold upon receipt of order. All contracts and agreements are made subject to flood, drouth, fire, frost, crop failure or other causes beyond our control. Prices are f. o. b. Berlin, Maryland.

NON-WARRANTY:We give no warranty expressed or implied, the purchaser assuming all risk and responsibility of transportation, planting, growth, life of stock or any other matter on any stock we sell. We exercise the greatest care to keep our plants true to name and are willing at any time to replace from our own stock, on proper proof, all stock that may prove otherwise, or refund the amount paid, but it is mutually agreed that we shall not at any time be liable for a greater amount than the original cost.

COMPLAINTS: Complaints covering packing, quality or count must be made to us within five days after receipt of stock.

HARMEL PEONY COMPANY.

PLACE ORDERS EARLY: We do not substitute unless instructed by customer to do so. Money promptly returned for any varieties we are sold out of. 


\section{Excellent Profits}

\section{FROM}

\section{Commercial Cut-Flower Plantings}

About 3,600 to 5,000 plants required to set an acre.

We often sell from $\$ 1,000$ to $\$ 1,500$ worth of cut-flowers in one season, from an acre of Peonies. Sometimes, the returns are very much greater. Plant an acre. It should prove to be the most profitable acre you own.

\section{Suggestions For Planting}

Peonies should be planted in the fall, and are equally successful when planted at any time from Septmber first until the ground freezes too deep to allow planting. They succeed best in good quality, well drained garden soil, such as would produce a good crop of Irish Potatoes. Do not plant Peonies in very sandy soil-they are not likely to succeed

Place roots in their natural position, two to four feet apart (for permanent cut-flower planting, rows may be four feet apart, plants three feet apart in the row, or $3 \frac{1}{2}$ x $31 / 2$ feet will be preferred by some) with new eyes two inches below the surface of the ground. Many growers blant as close as $3 \times 3$ feet.

In application of pure raw ground bone (bone meal) roughly mixed with the soil will supply sufficient plant

$d$ for a year or two. A top dressing of hardwood ashes wuuld assist in quick root development.

Soil should be well prepared by plowing or spading and cultivating to depth of eight inches or more and allowed to settle for a few days prior to setting the roots.

On some types of soil (usially not necessary), a light covering of straw or leaves for the first winter will prevent the newly set roots from heaving out because of alternate freezing and thawing.

Remove covering from directly over the plants, in early spring, before Peonies come through the ground. When Peonies are up a few inches, cultivate thoroughly and often throughout the growing season.

Member American Peony Society

Member American Association of Nurserymen

Member Commercial Peony and Iris Growers Association

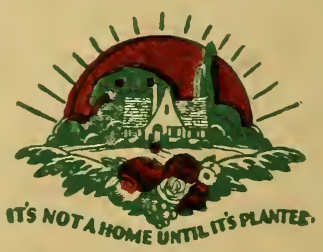

LARGE ORDERS: Please submit your "want list." On certain items, in quantity, it is often possible for us to quote lower than printed prices. 